\section{WHO calls the shots}

\section{Munich}

THE World Health Organization (WHO) and several other international organizations will next week launch an ambitious campaign for universal vaccination of children against diseases such as polio, tetanus and measles at the 'Children's Summit' in New York City. The creators of the 'Children's Vaccine Initiative' say that this will be the first time a broad network of agencies and world leaders will have given their support to the cause of better vaccines, which are the most cost-effective way of saving lives in the developing world.

WHO, the United Nations Development Programme (UNDP) and the United Nations Children's Fund (UNICEF) have joined forces to back an effort that they hope will attract a minimum of $\$ 15$ million a year over ten years for vaccine research and development. An expected 70 heads of state, including Soviet leader Mikhail Gorbachev and US President George Bush, will pledge their countries' support at the summit on 29-30 September.

The 'New York Declaration' sets goals of reducing the number of doses of vaccine required for immunization; combining many antigens in a single vaccine; making existing vaccines more heat-stable and affordable; and developing new vaccines against, for example, diarrhoea and acute respiratory infections.

An earlier goal - that of developing a single-dose, preferably oral "children's vaccine" that could immunize children against all endemic diseases - was dropped at a pre-summit meeting of WHO, UNDP and UNICEF experts in New York on 9-10 September.

According to Friedrich Deinhardt of the University of Munich, chairman of the WHO Scientific Advisory Group of Experts (SAGE), it was thought impossible in the near future to use a single vaccine carrier, such as a vaccinta virus, to carry antigens against as many as a dozen diseases. But, says Deinhardt, the use of existing techniques will allow the development of combination single-dose vaccines that would reduce the number of vaccinations necessary to immunize each child, thereby increasing effectiveness and reducing cost.

WHO has succeeded beyond all expectations since it began vaccinating children in 1974 under the Expanded Programme on Immunization. Whereas just 5 per cent of children in the developing world were being vaccinated in 1974 , the programme now vaccinates $66-81$ per cent of children against deadly diseases such as measles and polio.

Nevertheless, advocates of the Children's Vaccine Initiative are not satis- fied with the results of the Expanded Programme on Immunization. "Not a single new vaccine has been introduced in the developing world" since the programme began, says Barry Bloom of the Albert Einstein College of Medicine in New York.

And the vaccination programme is still plagued by technical problems, especially that of keeping the vaccines cold from the time they leave the manufacturer to the time they arrive at their destination, often in the tropics.

Even after next week's anticipated rousing start, the initiative will face two large challenges. For one, persuading researchers to work on vaccines will not be easy. "No one gives a prize for making polio vaccine more heat-stable", says Deinhardt. But Bloom, more of an optimist, says that the scientific problems might be interesting enough to catch the attention of researchers. "It's not just pickling a new bug, grinding it up and jabbing it into people", Bloom says. Instead, the research might require "using genetic engineering to make the vaccines less sensitive to heat", he says, "a project which is not trivial." The other challenge is raising money. Even though $\$ 150$ million sounds an impressive amount, Deinhardt says it is little more than "seed money" to get researchers and companies started on vaccine research. Developing a modern vaccine can cost as much as $\$ 20$ $\$ 100$ million, including expensive animal and human trials. According to Jim Sherry of UNICEF, US industry is ready to play a large part in developing better vaccines, but only if someone else pays the bill.

One likely target for the Children's Vaccine Initiative fund-raisers will be the US government. The list of supporters of the WHO Programme for Vaccine Development, an adjunct to the Expanded Programme on Immunization, does not include the United States but does include Australia, Italy, Japan, Norway, Sweden, Switzerland, the Rockefeller Foundation and UNDP.

US Senator Bill Bradley (Democrat, New Jersey) recently introduced a bill into the Senate to support the Children's Vaccine Initiative with as much as $\$ 125$ million a year, although the bill has little chance of becoming law. Nevertheless, Sherry believes that finding support will become easier for researchers who put forward good proposals to US agencies such as the National Institutes of Health.

Steven Dickman

\title{
GLOBAL WARMING
}

\section{France comes cleaner than clean}

\section{Paris}

France last week joined the list of countries preparing to take action to reduce greenhouse gas emissions. In a memorandum addressed to the Presidency and the Commission of the European Communities, the French secretary of state for the environment, Brice Lalonde, has declared that France will reduce levels of carbon dioxide emissions to "less than 2 tonnes per capita per year" in the next 25 years. The present emission level of carbon dioxide in France is about 2.3 tonnes per capita per year.

According to a spokesman at the ministry of foreign affairs in Paris, the announcement has been made to help advance negotiations at the ministerial meeting that will follow the Second World Climate Conference to be held in Geneva at the end of October.

Within the environment ministry which has just seen its annual budget almost double - a spokesman described the French proposal as "ambitious". But France is not a major producer of greenhouse gases, contributing only 1.7 per cent of world carbon dioxide emissions and about 2 per cent of all greenhouse gas emissions. Neighbouring West Germany contributes 3.3 per cent and the United States, 23 per cent of world carbon dioxide emissions (1989 OECD figures).
Energy production in France causes relatively little atmospheric pollution. France has few fossil fuel resources and, following the oil crisis of the 1970s, successive governments backed expansion of the nuclear energy programme. Now only about 9 per cent of the nation's energy needs are met from coal, compared with 32 per cent in Britain and 27 per cent in West Germany. By contrast, some 30 per cent comes from nuclear generators, compared with 7 per cent in Britain and less than 12 per cent in West Germany.

Over the past decade, France's reliance on coal has dropped by $\mathbf{4 0}$ per cent, while nuclear energy production has more than tripled.

Now, with the nuclear industry entering a period of decline, the Gulf war could have provoked new investment. But the industry minister, Roger Faroux, has said that he intends only to continue the present programme of reactor construction and has no plans for expansion. Instead, a more or less shelved programme to develop alternative energy sources will be revived, while new measures have been announced to promote energy saving. Of these, extra money will be available to develop a 'clean' car. Transport accounts for almost 40 per cent of the nation's carbon dioxide emissions.

Peter Coles 